Anita Shinta Kusuma, Atoillah Alfa Rikhi

Pengaruh Terapi Musik Klasik Kombinasi Aromaterapi Mawar Terhadap Tekanan Darah Pasien Hipertensi:

Literature Review

\title{
Pengaruh Terapi Musik Klasik Dikombinasi Dengan Aromaterapi Mawar Terhadap Tekanan Darah Pasien Hipertensi: Literature Review
}

\author{
Anita Shinta Kusuma ${ }^{1}$, Atoillah Alfa Rikhi \\ ${ }^{1), 2)}$ Akademi Keperawatan Ngesti Waluyo Temanggung
}

Korespondensi penulis: shinta.kusuma75@gmail.com

\begin{abstract}
Abstrak
Hipertensi sering disebut sebagai "silent killer" (pembunuh siluman), karena seringkali penderita hipertensi bertahun-tahun tanpa merasakan sesuatu dan tanpa disadari penderita mengalami komplikasi. Salah satu cara mengontrol tekanan darah pada pasien hipertensi yaitu menggunakan intervensi terapi nonfarmakologi. Menurunkan hipertensi menggunakan terapi nonfarmakologi, salah satunya yaitu menggunakan musik klasik kombinasi dengan aromaterapi mawar. Penelitian ini menggunakan metode Literature Review. Database yang digunakan yaitu: Google Cendikia, Garuda dan ProQuest. Dari beberapa literature review memaparkan terapi musik klasik dan aromaterapi mawar dapat efektif dalam menurunkan tekanan darah pada hipertensi. Didapatkan pemberian terapi musik klasik dikombinasi dengan aromaterapi mawar dapat digunakan sebagai terapi pendamping untuk menurunkan tekanan darah dan perlunya penelitian lebih lanjut dalam intervensi nonfarmakologi lain yang dapat menurunkan tekanan darah pada hipertensi.
\end{abstract}

Kata kunci: musik klasik; aromaterapi mawar; tekanan darah; hipertensi

\section{PENDAHULUAN}

Data World Health Organization (WHO) tahun 2015 menunjukkan sekitar 1,13 Miliar orang di dunia menyandang hipertensi, artinya 1 dari 3 orang di dunia terdiagnosis hipertensi. Jumlah penyandang hipertensi terus meningkat setiap tahunnya, diperkirakan pada tahun 2025 akan ada 1,5 Miliar orang yang terkena hipertensi, dan diperkirakan setiap tahunnya 10,44 juta orang meninggal akibat hipertensi dan komplikasinya (World Life Expectancy, 2018)

Indonesia menduduki peringkat pertama dengan penderita stroke terbanyak di Dunia World Life Expectancy (2018) Hasil Riset Kesehatan Dasar Riskesdas tahun 2013 menunjukkan prevalensi hipertensi secara nasional mencapai $25,8 \%$. Penderita hipertensi di Indonesia diperkirakan sebesar 15 juta tetapi hanya 4\% yang hipertensi terkendali (Tarigan et al., 2018)

Hipertensi sering disebut sebagai "silent killer"(pembunuh siluman), karena seringkali penderita hipertensi bertahun-tahun tanpa merasakan sesuatu dan tanpa disadari penderita mengalami komplikasi, adapun gejalagejala pada hipertensi seperti pusing, sakit kepala, bahkan sampai gangguan penglihatan biasanya terjadi pada gejala hipertensi lanjut saat angka tekanan darah sudah berada pada angka tertentu (Triyanto, 2014). Terdapat berbagai cara perawatan nonfarmakologi dalam menangani pasien hipertensi seperti menggunakan terapi musik klasikal. Terapi music klasik memiliki tempo sekitar 60 ketukan/menit yang dapat memberikan efek relaksasi. Rangsangan musik ini mengaktivasi jalur- jalur spesifik di dalam berbagai area otak, yang berhubungan dengan perilaku 
emosional. Keadaan rileks inilah yang akan menurunkan tekanan darah. Alunan musik juga menstimulasi tubuh untuk memproduksi molekul yang disebut Nitric Oxide (NO). Molekul ini bekerja pada pembuluh darah sehingga dapat mengurangi tekanan darah (Hidayah et al., 2015)

Terapi musik sangat mudah digunakan dan terjangkau. Terapi musik terbukti dapat menurunkan tekanan darah karena dapat mempengaruhi ketengangan yang membuat lebih rileks pada diri seseorang. Saat tubuh rileks, otak merangsang pengeluaran endorphine dan serotonin yang merupakan hormon yang dapat membuat tubuh seseorang menjadi lebih rileks pada saat seseorang mengalami (Djohan, 2016).

Sejalan dengan penelitin diatas, penelitian yang dilakukan oleh Mariza \& Kalsum, (2016) dengan menggunakan media aromaterapi bunga mawar mendapatkan hasil $\mathrm{p}=$ 0.000 yang dapat diartikan terdapat perbedaan yang significant antara pre dan post test yaitu setelah diberikan intervensi didapatkan hasil penelitian menunjukan terjadi penurunan tekanan darah pada responden. Penulis menjelaskan pada saat aromaterapi mawar dihirup, molekul yang mudah menguap akan membawa unsur aromatik yang akan merangsang emosional yang menyebabkan perasaan yang lebih tenang dan rileks serta dapat memperlancar aliran darah sehingga didapatkan dapat menurunkan tekanan darah pada pasien hipertensi

Berdasarkan latar belakang diatas penulis tertarik untuk melakukan penelitian dengan mengabungkan antara terapi musik klasik dengan aromaterapi mawar pada pasien hipertensi, Peneliti tertarik untuk mengetahui apakah manfaat yang akan dihasilkan lebih signifikan jika terapi diatas dikombinasikan atau justru sebaliknya, dan apakah akan memiliki manfaat yang sama jika dilakukan pada pasien hipertensi.

\section{METODE}

Metode yang digunakan dalam penelitian ini adalah literature review. Penelitian ini akan mensintesis literatur pengaruh pada tekanan darah setelah di berikan terapi nonfarmakologi yaitu dengan cara pemberian musik klasik, aromaterapi, dan gabungan antara musik klasik dan aromaterapi. Penilaian tekanan darah akan dilakukan dua kali yaitu sebelum dan sesudah diberikan intervensi.

Hasil penelitian yang dilakukan telusur pada penelitian ini menggunakan database google scholar, portal Garuda. Semua tulisan ilmiah yang ditelusur kemudian dibaca dan dilakukan evaluasi. Kesesuaian topik artikel satu dengan yang lainnya dievaluasi, kesamaan prosedur intervensi dianalisis, validitas jurnal dan fokus studi, serta membuat ringkasan dalam tabel. Terakhir, penulis membuat dan menyimpulkan satu cerita ilmiah yang lengkap tentang pengaruh pemberian terapi musik klasik, pengaruh pemberian aromaterapi mawar serta kombinasi keduanya terhadap penurunan tekanan darah pada pasien hipertensi.

\section{HASIL}

Pada penelitian Syahril (2019) dilakukan dengan sampel orang 30 orang di panti sosial tresna werdha teratai palembang dan semua sampel adalah lansia dan dari 70 lansia terdapat 44 lansia dengan hipertensi. Pada penelitian ini menggunakan jenis penelitian Pre Experimental Design dengan rancangan penelitian One- 
group pre and post test design yang dilakukan pada satu kelompok tanpa kelompok control. Kelompok subjek diobservasi sebelum dilakukan intervensi (pre-test) kemudian diobservasi lagi setelah intervensi (post-test). Intervensi yang diberikan berupa terapi musik klasik yang akan diberikan pasien hipertensi selama 7 hari dengan durasi 17 menit dan akan diberikan perbandingan tekanan darah sebelum dan sesudah dilakukan terapi musik klasik.

Hasil analisis univariat diketahui bahwa sebelum diberikan terapi musik klasik dari 30 responden tekanan darah tinggi sebanyak 19 responden dan tekanan darah rendah sebanyak sebanyak 11 responden. Sesudah diberikan terapi musik klasik dari 30 responden dengan hasil tekanan darah tinggi sebanyak 8 responden sedangkan tekanan darah rendah sebanyak sebanyak 22 responden, dan hasil tersebut membuktikan adanya pengaruh musik klasik terhadap penurunan tekanan darah pada pasien dengan hipertensi karena musik klasik dapat membuat lebih rileks dan lebih nyaman maupun dalam keadaan depresi

Hasil yang didapatkan dalam penelitian Putri et al., (2019) menjelaskan bahwa adanya pengaruh pemberian aromaterapi mawar terhadap penurunan tekanan darah disebabkan karena pada bunga mawar terdapat kandungan-kandungan senyawa kimia yang memiliki aroma khas yang akan diterima oleh saraf penciuman (nervus olfaktorius), selanjutnya impuls akan diteruskan ke hipotalamus dan mempengaruhi sistem saraf pusat. kemudian akan dipersepsikan sensasi relaksasi yang akan menimbulkan efek menenangkan. Keadaan tubuh yang tenang akan menyebabkan sistem saraf parasimpatis memicu penurunan denyut jantung yang akan menurunkan curah jantung dan akan menurunkan tekanan pada dinding-dinding pembuluh darah.

Pengambilan sampel pada pasien hipertensi tidak hanya pada lansia saja tapi juga pada usia muda. Sampel diambil secara acak tanpa memilih latar belakang pendidikan berjumlah 17 orang yang mengalami tekanan darah tinggi dengan responden lakilaki 6 dan perempuan 11 dengan rentan umur 20-40 tahun 7 dan 40-60 tahun 10. Dapat disimpulkan bahwa perempuan lebih banyak mengalami tekanan darah tinggi dengan rentang umur 40-60 tahun

Penelitian menurut Maisi et al., (2017) yang dilakukan pada 11 November 2016 hingga 8 Januari 2017 di wilayah kerja dari Pusat Kesehatan Masyarakat Gayamsari, Tlogosari, Kedungmundu, Ngesrep, Pudakpayung, Gunungpati, dan Ngaliyan Semarang. Pada penelitian ini ada 52 wanita dengan keadaan hamil dengan hipertensi dan di ambil secara acak dari batas usia berapapun dan metode yang di gunakan dalam penelitian ini adalah Penelitian ini menggukan metode quasy experimental design dengan pretest posttest control group.

Penelitian ini dilakukan dengan cara membandingkan hasil intervensi penelitian kepada pasien hipertensi yaitu: 1). hasil intervensi dari pemberian aromaterapi, 2). hasil intervensi dari pemberian terapi musik klasik, 3) hasil intervensi dari pemberian aromaterapi dikombinasikan dengan terapi musik klasik. Didapatkan hasil jika kelompok pasien hipertensi yang mendapatkan intervensi pemberian aromaterapi dikombinasikan dengan terapi musik klasik mengalami 
penurunan tekanan darah yang lebih signifikan dibandingkan dengan kelompok pasien hipertensi yang hanya mendapatkan intervensi pemberian aromaterapi saja dan kelompok pasien hipertensi yang hanya mendapatkan intervensi pemberian terapi musik klasik saja.

Penelitian yang memberikan intervensi pemberian aromaterapi dikombinasikan dengan terapi musik klasik tersebut dilakukan kurang lebih selama 2 bulan dan didapatkan hasil jika intervensi pemberian aromaterapi dan musik klasik cocok apabila dikombinasikan untuk menurunkan tekanan darah pada pasien hipertensi. Intervensi pemberian aromaterapi dikombinasikan dengan terapi musik klasik bertujuan untuk membuat tubuh dan pikiran menjadi lebih rileks dan lebih nyaman. Intervensi pemberian aromaterapi lavender dan kombinasi musik klasik juga didapatkan jika signifikan untuk menurunkan sistolik-diastolik tekanan darah pada ibu hamil dengan hipertensi

\section{PEMBAHASAN}

Berdasarkan tiga jurnal tersebut terapi musik klasik dikombinasikan dengan aaromaterapi bunga mawar effective dalam menurunkan tekanan darah pada pasien hipertensi. Menurut Ismarina (2015) dalam Syahril, (2019) terapi musik adalah penggunaan musik sebagai alat terapi untuk memperbaiki, memelihara, meningkatkan keadaan mental, fisik dan emosi. Bagi penderita hipertensi atau tekanan darah tinggi, musik dapat dijadikan sebagai terapi yang efektif untuk menurunkan tekanan darah.
Pernyataan diatas didukung oleh Jasmarizal (2013) dalam Syahril (2019) bahwa mendengarkan musik klasik dapat mengurangi kecemasan dan stres sehingga tubuh mengalami relaksasi, yang mengakibatkan penurunan tekanan darah dan denyut jantung. Selain terapi nonfarmakologi musik klasik untuk pasien hipertensi, pemberian aromaterapi juga dapat diberikan kepada pasien hipertensi.

Hal tersebut sesuai dengan hasil penelitian Mariza dan Kalusum (2016) dalam Putri et al (2019) yang memaparkan jika terdapat pengaruh pemberian aromaterapi mawar terhadap penurunan tekanan darah. Hal tersebut dikarenakan pada bunga mawar terdapat kandungan-kandungan senyawa kimia yang memiliki aroma khas yang akan diterima oleh saraf penciuman (nerfus olfaktorius). Selanjutnya impuls akan diteruskan ke hipotalamus dan mempengaruhi sistem saraf pusat yang kemudian akan dipersepsikan sensasi relaksasi sehingga menimbulkan efek menenangkan.

Keadaan tubuh yang tenang akan menyebabkan sistem saraf parasimpatis memicu penurunan denyut jantung yang akan menurunkan curah jantung dan akan menurunkan tekanan pada dinding-dinding pembuluh darah. Hal tersebut sesuai dengan penelitian Nurachman (2004) dalam Putri et al., (2019) yang menjelaskan bahwa aromaterapi mawar memiliki minyak esensial oil yang dihirup dan dipersepsikan oleh otak untuk memberikan reaksi agar membuat rileks tubuh karena mestimulus produksi endoprin.

\section{KESIMPULAN}

Berdasarkan literature review yang telah dilakukan terkait pengaruh pemberian aromaterapi mawar 
Anita Shinta Kusuma, Atoillah Alfa Rikhi

Pengaruh Terapi Musik Klasik Kombinasi Aromaterapi Mawar Terhadap Tekanan Darah Pasien Hipertensi:

Literature Review

terhadap penurunan tekanan darah didapatkan jika aromaterapi mawar memberikan rasa nyaman dan rileks pada pasien hipertensi sehingga berdampak terhadap penurunan tekanan darah. Pemberian terapi musik klasik juga memberikan manfaat untuk mengurangi kecemasan dan stres sehingga tubuh mengalami relaksasi yang berdampak terhadap penurunan

\section{DAFTAR PUSTAKA}

Djohan. (2016). Terapi Musik, Teori dan Aplikasi. Yogyakarta: Galang Press.

Hidayah, N., Darmanik, S., \& Elita, V. (2015). Tekanan arah Pada Penderita Hipertensi. https://ejournal.unsrat.ac.id/ind ex.php/jkp/article/view/2172/1 730

Maisi, S., Suryono, Widyawati, M., Suwondo, A., \& Kusworowulan, S. (2017). Effectiveness of Lavender Aromatherapy and Classical music Therapy in Lowering Blood Pressure in Pregnant Women With Hypertension. https://www.researchgate.net/p ublication/331213069_EFFEC TIVENESS_O

F_LAVENDER_AROMATHE RAPY_AND_CLASSICAL_ MUSIC_THER

APY_IN_LOWERING_BLOO D_PRESSURE_IN_PREGNA NT_WOMEN_ WITH_HYPERTENSION/fullt ext.pdf

Mariza, A., \& Kalsum, A. U. (2016). Pemberian Aromaterapi Bunga Mawar Terhadap Penurunan Tekanan Darah pada Wanita Lanjut Usia di Uptd Panti Sosial Lanjut Usia Tresna Werdha Natar Lampung Selatan. 30-35. tekanan darah dan normalnya denyut jantung. Kombinasi antara musik klasik dengan aromaterapi mawar merupakan terapi yang dapat menurunkan tekanan darah pada pasien hipertensi, dan membantu pasien untuk relaksasi, mengurangi kecemasan dan stress serta dapat dilakukan secara rutin.

Putri, N. D., Sarifah, S., \& Nanang, S. (2019). Pemanfaatan Aroma Terapi Mawar Terhadap Penurunan tekanan Darah Pada Pasien Hipertensi. http://repository.itspku.ac.id/11 2/1/2016011945.pdf

Syahril, S. (2019). Pengaruh Terapi Musik Klasik Terhadap Penurunan Tekanan Darah Pada Pasien Hipertensi di Panti Sosial Tresna Werdha Teratai Palembang. https://ejournal.stikesmp.ac.id/i ndex.php/maskermedika/article /view/356

Tarigan, A. R., Lubis, Z., \& Syarifah. (2018). Pengaruh Pengetahuan, Sikap dan Dukungan Keluarga Terhadap Diet, Hipertensi di Desa Hulu Kecamatan Pancur Batu Tahun 2016. Jurnal Kesehatan, 11(1), 9-17.

Triyanto, E. (2014). Pelayanan Keperawatan Bagi Penderita Hipertensi Secara Terpadu. Yogyakarta: Graha Ilmu.

World Life Expectancy. (2018). World Health Rankings. https://www.worldlifeexpectan cy.com 